\title{
Ruslands økonomi under sanktioner
}

Af Natalia Orlova [interviewet af Udenrigs]

Siden Rusland i 2014 annekterede Krim og gav sin militære og politiske støtte til separatisterne i Østukraine, har Rusland været underlagt økonomiske sanktioner fra henholdsvis USA og EU. I august 2018 vedtog USA's kongres et nyt sæt sanktioner, og EU forlængede sine sanktioner mod Rusland i juli 2018. I 2015 advarede Den Internationale Valutafond om, at Rusland ville være i recession, da økonomien var skrumpet med 2,8 procent. Det var dog ikke kun sanktionerne, der påvirkede Ruslands økonomi men også det store fald i oliepriserne. På det seneste er den russiske økonomi i bedring med en lille vækst på 1,4 pct. af BNI i 2017, og den forventes at vokse endnu mere i 2018. I foråret 2018 lige før det russiske præsidentvalg og VM i fodbold, som blev afholdt i Rusland, opstod en ny politisk og diplomatisk krise mellem
Rusland og Vesten om spørgsmålet om et kemisk våbenangreb i Syrien og forgiftningen af den tidligere spion Skripal og hans datter i den engelske by Salisbury. Disse nye uenigheder har udløst nye sanktioner mod Rusland.

Udenrigs: Du mener, at der er hverken økonomisk krise eller økonomisk vakst i Rusland. Hvorfor?

Natalia Orlova: Ruslands økonomi er meget anderledes end mange af de udviklingsøkonomier, der netop nu lider af kapitalflugt på grund af investorernes bekymring for deres $ø$ konomiske modstandsdygtighed i en tid med udsigt til stigende renter.

For det første har Rusland siden år 2000 - og i særdeleshed siden 2008 ført en meget disciplineret pengepolitik. I 2014 (da olieprisen faldt drastisk, og man indførte internationale økonomiske sanktioner mod Rusland) lod

Natalia Orlova er professor og forskningschef ved den russiske Alfa-Bank. Interviewets formål er at kaste lys over hovedproblemstillingerne i den russiske økonomi i præsident Putins fjerde præsidentperiode. I dag er de fleste af de større russiske banker i vid udstrækning regeringsstyret gennem direkte eller indirekte statsejerskab. Alfa-Bank er imidlertid den førende private bank i den russiske banksektor. Natalia Orlova er medlem af Det Rådgivende Råd for Pengepolitik under præsident Putin. I 2010 blev hun udnævnt til et professorat ved Higher School of Economics i Moskva. 
man rublen flyde med det internationale valutamarked for at beskytte den russiske centralbanks valutareserver og for at modvirke inflation. For det andet har man siden 2012 praktiseret mådehold i forhold til de offentlige budgetter. Rusland har en statsgæld på kun 13 pct. af BNP, hvilket efter internationale standarder er ekstraordinært lavt. Vi har i Rusland en virksomhedsgæld (intern og ekstern), på omkring 60 pct. af BNP, og en russisk privatgæld på kun 14 pct. af BNP. Den russiske økonomi er med andre ord ikke overbelånt.

Normalt ville disse faktorer tiltrække interesse og investeringsvillighed fra udenlandske investorer. Denne tendens synes imidlertid at udeblive. Vi ser derimod, at det russiske kapitalmarked lider - i lighed med det tyrkiske og det argentinske. Mit gæt er, at det skyldes, at de russiske politikere har forpasset muligheden for at præsentere en overbevisende vækstplan for Rusland. Investorer ser efter lande med en lys fremtidsudsigt, lande der siger, 'her er en plan for, hvordan vi kan videreudvikle vores eksportsektor, hvordan vi i højere grad kan blive selvforsynende, eller hvordan vi når et helt tredje mål.' Grundlæggende skal planen give et svar på, hvordan landet planlægger at levere vækst.

I Rusland er hovedfokus i den økonomiske diskussion budgetstyring og udgiftspolitik. Det er positivt, at der de seneste år har været fokus på at forbedre skatteinddrivelsen, men for virksomhederne har dette de facto resulteret i et markant voksende skat- tetryk, som har stækket deres vækstmuligheder. Dertil skal man lægge, at sanktionerne naturligvis mindsker lysten i den russiske befolkning til at investere lokalt. Min pointe er dog, at selv før indførelsen af sanktionerne var investorerne varsomme med hensyn til det russiske finansielle marked - ikke fordi Ruslands politik har slået fejl på samme måde som i en række udviklingsøkonomier, men fordi vækstfortællingen var utilstrækkelig med en årlig vækst i BNP på under to pct. siden 2013.

Udenrigs: Staten spiller en stadig større rolle i Ruslands økonomi. I stigende grad er det statsejede eller statslige virksomheder, der skal øge vaekst og investering $i$ den private sektor. Hvor stor er statens andel af det private marked?

Natalia Orlova: Statens tilstedeværelse og betydning på markedet er ofte vanskelig at måle. Der er forskellige måder at anslå betydningen, eksempelvis kan man se på statens investeringsniveau målt i forhold til BNP. Det tal er omtrent 35 pct. af BNP for Rusland, hvilket er relativt lidt. Omvendt er det velkendt, at markedet er skævvredet - ikke af store statslige udskrivninger, men på grund af et strukturelt problem med statsejede virksomheder. Betydningen deraf er meget vanskelig at estimere, fordi resultatet vil afhænge af den anvendte regnemetode. Man kan eksempelvis sammenregne værdien af statens aktier i virksomheder på det finansielle marked. Det giver dog ikke nødvendigvis et retvisende billede af statens betydning for marke- 
det. Personligt undersøger jeg ikke de generelle men mere snævre, sektorspecifikke indikatorer for at vurdere omfanget af statens indblanding i den private sektor i Rusland. For eksempel har investeringer i tre regioner, nemlig Moskva, Vladivostok og det sydlige Rusland (red. Krim), udgjort et sted mellem 80 og 90 pct. af væksten $\mathrm{i}$ investeringerne sidste år, og ud af disse er hovedparten gået til investeringer i statsfinansierede projekter. Det er en ganske høj andel. Man kan også se på banksektoren. Andelen af statslige banker udgjorde for bare ti år siden omkring 50 pct. af den finansielle sektor, men nu er andelen vokset til mellem 60 pct. og 70 pct. Det er på sin vis paradoksalt, at selvom visse sanktioner har været målrettet de statslige banker, er det netop dem, der har klaret sig på trods af det ugunstige erhvervsklima. Dette er blot to eksempler, men de illustrerer en generel pointe.

Udenrigs: Men er det ikke en tilbagevenden mod planøkonomi? Man har enorme investeringsprojekter betalt af staten, og staten ejer en betragtelig del af nøglevirksomhederne i centrale sektorer?

Natalia Orlova: Efter Sovjetunionens sammenbrud valgte de tidligere plan$\varnothing$ konomier forskellige veje. Ruslands vej blev en abrupt økonomisk transition med hurtige og meget dramatiske ændringer af økonomien. Kina tog en anden vej med en blødere overgang. Når man ser tilbage på erfaringerne fra de seneste 25 år, mener en del russiske myndighedspersoner og politikere, at den kinesiske måde at håndtere den økonomiske transformation var mere hensigtsmæssig. Kina har oplevet et par årtier med meget høj økonomisk vækst. Hvad der især har adskilt Kina og Rusland i de forgangne årtier er, at Kina er blevet en $\varnothing$ konomi, der udgøres af store virksomheder og store banker, mens det russiske erhvervsliv i højere grad er disintegreret og fragmenteret. Mange russiske politikere ser sig nu kaldet til at følge det kinesiske eksempel ved at favorisere fremkomsten af store, statsejede virksomheder. Det var altså ikke den oprindelige hensigt at genindføre sovjetisk økonomi ad bagdøren, selvom virksomhederne i realiteten ofte baserer sig helt eller delvist på statseje. Man har haft den opfattelse, at store, statsstøttede virksomheder har bedre adgang til og mulighed for at etablere sig på nye markeder. Men dette er baseret på en fejldiagnose, nemlig at årsagen til, at de russiske virksomheder ikke havde held til at etablere sig på de globale markeder og sikre vækst, skulle findes i, at de var private. Forklaringen er snarere, at Rusland, modsat Kina, ikke havde en langtidsstrategi for $\sin ø$ konomiske udvikling. Under alle omstændigheder er resultatet, at statsejede virksomheder og statsfinansierede projekter spiller en stadig vigtigere rolle i den russiske økonomi.

Udenrigs: Hvad med almindelige russere? Jeg ved, at mange oplevede trange kår op gennem 1990'erne, som var en svor periode $i$ Rusland. Men så oplevede mange opgangstiderne $i$ 00'erne, og siden er økonomien mere 
eller mindre stagneret. Marker folk stagnation - er de utilfredse? Forstår almindelige mennesker Ruslands økonomiske situation, og ved de, hvad man bør gøre ved det? Eller er der stadig en fornemmelse af, at tingene ikke er så slemme, som de kunne vare? Natalia Orlova: Jeg tror, at de fleste mener, at de har det udmærket. Internationale eksperter antager ofte, at det vil fremprovokere protester, når Ruslands vækst går i stå. Man må forstå, at de fleste russere sammenligner nutidens $ø$ konomiske situation, deres indkomst i dag og deres forbrugsmuligheder med, hvad de oplevede i 1990'erne. 90'erne var en grim oplevelse for mange russere, og det står stadig frisk i erindringen. Mange mennesker kan huske deres livssituation som markant værre for blot få år siden. Derfor siger majoriteten af russerne, 'det er blot en vækstpause, bare rolig.' Samtidig modvirkes den generelle oplevelse af stagnationen af, at almindelige mennesker føler krisen kradse i mindre omfang end virksomhederne. Dette skyldes vores demografiske udfordring. Den russiske befolkning skrumper, arbejdsstyrken mindskes, og arbejdsløsheden er på kun 4,7 pct. Så selv med en vækst på bare 1-2 pct. kæmper virksomhederne for at tiltrække kvalificeret arbejdskraft, hvilket medfører, at reallønnen stiger. Lønstigningerne indikerer, at de demografiske udfordringer især går ud over virksomhederne, i mindre grad befolkningen. Faktisk er det nu sådan i Rusland, at man ikke behøver at frygte at blive arbejdsløs, fordi vi er tæt på at have fuld beskæftigelse.
Måske er markedet en anelse sværere i nogle helt specifikke sektorer, men i almindelighed er det ikke et problem, som flertallet er berørt af, og derfor føler folk sig relativt sikre.

I tillæg til den gunstige lønudvikling er der kommet en del lånemuligheder, som ikke fandtes tidligere. Realkreditlån klarer sig bedre end andre bankprodukter, og for et par år siden tillod regeringen folk at investere den såkaldte 'maternity capital' (Læs evt. her: http://www.pfrf.ru/en/matcap/) i beboelsesbyggeri, hvilket har medført en stigning i efterspørgslen på huslån.

Udenrigs: Så man kan måske sige, at en del af økonomien går ind i statsejede virksomheder. På den anden side ser vi øget privatisering på individniveau? Natalia Orlova: Hvis du spørger mig, var russisk økonomi også meget afhængig af staten $i$ årene med omfattende markedsreformer. For eksempel arbejdede en stor del af befolkningen i det offentlige, enten for offentlige virksomheder eller i den offentlige sektor. I øjeblikket er omtrent 25 pct. af arbejdsstyrken, svarende til 19 mio. mennesker, beskæftigede i den offentlige sektor. Sammenlagt med dem, der er beskæftigede i offentligt ejede virksomheder, er det formentlig 30-35 pct. af arbejdsstyrken. Det er en meget høj grad af afhængighed af staten.

Det er værd at nævne, at denne afhængighed delvis skyldes, at Rusland ikke har været i stand til at finde nye måder at integrere sig i verdensøkonomien i løbet af det seneste årti. Den russiske økonomi er fortsat baseret på eksport af råstoffer, og den er relativt 
lukket for udenlandske investeringer. Dette er dårligt nyt for udsigten til $ø$ konomisk vækst men beskytter samtidig Rusland mod en dyb finansiel krise i relation til de globale markeder. Sanktionerne i 2014 tvang russiske virksomheder og banker til at konsolidere sig, alt imens andre lande vedblev at låne på de globale markeder. Som et resultat heraf blev Rusland betydeligt bedre forberedt på 'the emerging market sell-off.'

For at gå tilbage til dit spørgsmål angående forbrugerne under sanktionerne: mens talrige virksomheder blev underlagt sanktioner, unddrog forbrugerne sig i store træk effekten af sanktionerne. Virksomheder, der solgte forbrugsvarer, var derfor i en relativt gunstig situation.

\section{Udenrigs: Men hvis amerikanske} sanktioner er rettet mod den finansielle sektor, vil det så ikke også ramme vital infrastruktur i den russiske økonomi? Jeg mener, når man har opbygget en infrastruktur med et finansielt marked og et finansielt system etc., for dernoest at se sanktionerne nedbryde dem igen og tvinge banker ud på fallittens rand. Er det ikke noget, der svoekker tilliden til den russiske økonomi og finansielle sektor?

Natalia Orlova: Det har faktisk den modsatte effekt. Når russiske bankkunder læser om sanktioner i avisen, og de kender til de negative erfaringer, man har gjort sig blandt andet i Iran, indgyder det mindre tillid til den globale økonomi, og man har tendens til at værge sig mod globaliseringen. I et vist omfang fremkalder sanktionerne en mere indadskuende og selvstændig økonomi, og den naturlige konsekvens bliver, at kunderne stoler mere på statsejede banker og virksomheder end på de private, der er afhængige af globale strømninger og kan rammes af eksempelvis sanktioner. Dette har også været medvirkende til den voksende andel af statsejede enheder de seneste år.

\section{Udenrigs: Jeg har også hørt det} argument fremført, at sanktionerne ikke burde ramme Rusland, men $i$ stedet specifikke russere.

Natalia Orlova: Tanken er rigtig, men i Rusland er det meget svært at adskille disse to ting. I mange russeres øjne er sanktionerne rettet mod landet.

\section{Udenrigs: Rusland har netop} indført en ny pensionsreform, og regeringen har hovet skatterne. Ser du en andring i den sociale kontrakt fra prosident Putins første regeringsperiode til $\mathrm{nu}$ ?

Natalia Orlova: En af grundpillerne i den russiske $ø$ konomi har indtil for nyligt været, at staten tog sig af befolkningen. Det var især udtalt i årene 2008-2009 umiddelbart efter den globale krise - og den russiske krise, - hvor staten besluttede at fortsætte indekseringen af pensionsudbetalinger, hvilket i praksis betød stødt voksende pensioner, fx med ca. 30 pct. i årene 2009-2010. Denne beslutning afspejlede præsident Putins ønske om at dele de midler, man akkumulerede fra olieindtægter, med befolkningen. $\mathrm{Nu}$ har fokus forrykket sig en smule, og regeringens hovedprioritet er at 
fastholde et balanceret budget, hvilket resulterer i faldende sociale goder og ydelser. En af årsagerne til dette skift er demografien, der presser arbejdsløsheden ned, lønningerne op og på mange måder har gjort livet nemmere for forbrugerne. Dertil skal man lægge store udsving i priserne på almindelige forbrugsgoder, som har givet staten incitament til at tage sine økonomiske forholdsregler. Det mest synlige bevis på dette skift i den økonomiske politik er, at privatforbruget i 2015 og 2016 faldt med 15 pct.

\section{Udenrigs: Selvfølgelig er der ekstreme} uligheder i Rusland, men der eksisterer også en begrundet forventning til staten om, at den tager vare på sine borgere. Morker du et skred i denne mentalitet, eller vil den forblive en stork vardi for russerne?

Natalia Orlova: Jeg mener, at staten stadig forsøger at fastholde billedet af, at den tager sig af befolkningen, dog på en lidt anden måde: hvor man før underholdt folk gennem overførselsindkomster, er det aktuelle sigte med den økonomiske politik at stimulere investering i infrastruktur og derigennem hjælpe befolkningen. Dette er grunden til, at en betydelig del af investeringerne i dag går til opførelse af boligbyggerier, hvilket sænker boligpriserne og leveomkostninger for almindelige russere. Indirekte er det også en måde at reducere ulighed og omfordele velstand fra middelklassen, der hidtil har høstet frugterne af stigende boligpriser, til dele af befolkningen, der er ringere stillet.
Udenrigs: En ting Putin novnte i sin tale den 1. marts var, at han havde til hensigt at reformere økonomien. Er der udsigt til det?

Natalia Orlova: Præsidentens udmelding tager konkret form i en række regeringsudspil og dekreter, der tilsammen danner rammen om en reform af økonomien. I 2012 udsendte regeringen første gang, hvad man dengang døbte majdekreterne. I 2018 er de blevet opdateret og benævnes nu 'de nye majdekreter.' De nye dekreter er især fokuserede på uddannelse og sundhedsvæsen, som bliver to kerneområder de kommende år. Når man går længere ned i disse fokusområder, opdager man, at de handler om byggebranchen. Med andre ord ligger fokus på at opføre nye skoler og nye hospitaler. Det er gode tiltag, men opmærksomheden på kvaliteten af den sundhed eller undervisning, man leverer, udebliver.

\section{Udenrigs: For indevarende er den} russiske økonomi storkt afhongig af olieindtoegter og lider under den lave markedspris på olie og gas. Man har et statsbudget, der baserer sig på en oliepris i omegnen af 50 dollar pr. tønde. Vil det russiske statsbudget vore afhoengig af olieprisen? Natalia Orlova: Faktisk er en oliepris på 50 dollar per tønde, som ganske rigtigt er, hvad der skal til for at balancere det russiske statsbudget, en meget lav pris. Denne prissætning afspejler derfor i høj grad en budgetdisciplin fra myndighedernes side. I årene mellem 2010 og 2014 var 'breakeven' olieprisen for det russiske budget tættere på 
100-110 dollar. Andelen af det russiske statsbudget, der er udgjort af olieindtægter, er i dag faldet fra 50 pct. til 40 pct. Rusland forsøger at begrænse sin afhængighed af olieindtægter.

Rusland har mange 'start-up' virksomheder, men det er stadig en lille sektor. Hvis du holder dem op imod forbrugsvaresektoren, metalsektoren og byggesektoren - alle vigtige dele af den russiske økonomi - vil du finde, at 'start-ups' udgør mellem 1-2 pct. af BNP. Efter 2014 talte man meget om importsubsidier af landbrugsvarer, men selv denne sektor udgør kun fire procent af den samlede økonomi. Så selvom vi har et meget innovativt og dynamisk 'start-up' miljø, er det ikke stort eller hurtigt voksende nok til grundlæggende at ændre ved BNP-strukturen.

\section{Udenrigs: I Danmark og i Vesten} taler vi meget om, at man for at drive forretning i Rusland må have et 'krysja' (red.: et 'tag', som man betaler beskyttelsespenge for). Er det stadig sådan?

Natalia Orlova: Hvis man ønsker at drive en lille virksomhed i Rusland, er det meget lettere i dag. Problemet i Rusland er, at man har et relativt stort antal små virksomheder og et stort antal store virksomheder, men man har få af mellemstørrelse. Så snart virksomheden vokser bare en smule, begynder besværlighederne. Men forretningsgangene har ændret sig, og vi er ude over 90'erne. Jeg tror især, at ideen om krysja opstod som konsekvens af, at procedurerne for virksomheder i høj grad var uigennemskuelige. Det er grunden til, at krysja som koncept blev en måde for virksomhederne at sikre eller garantere deres forretning i Rusland. Det er i nogen grad sammenligneligt med de 'forsikringer', man betaler i visse udviklingslande. I Rusland er krysja din forsikring, dvs. en måde at sikre dig mod usikkerhederne. Det var i alt fald den måde, mange virksomheder forstod det. Det var ganske enkelt en måde at undgå de usikkerheder, der er forbundet med at drive virksomhed i Rusland, til forskel for eksempelvis forretning inden for EU, hvor procedurerne er klare. Det var naturligvis også en måde at sikre sin virksomhed mod for meget konkurrence.

Det er vigtigt at forstå, at vi i Rusland ikke har en rodfæstet tradition for at drive privat virksomhed. Selv i dag arbejder 25 pct. af russerne, svarende til 18 mio. mennesker, for staten. Dertil kommer antallet, der er beskæftiget i statslige virksomheder, hvilket formentlig når op omkring 30-35 pct. af arbejdsstyrken. Vi har desuden 40 mio. pensionister ud af en befolkning på 140 mio., så i omegnen af 30 pct. af den russiske befolkning er direkte afhængig af staten. Mange mennesker betragter derfor staten som hovedkilden til en fast indkomst. 